\title{
The COVID-19 Church-Closure Cases and the Free Exercise of Religion
}

\author{
Mark Storslee
}

Assistant Professor, Penn State Law School; McDonald Distinguished Fellow, Emory University School of Law

\begin{abstract}
In a series of cases over the past year, the U.S. Supreme Court upheld then struck down COVID-19related restrictions on worship in various states across the country. Those decisions clarified that, under the Free Exercise Clause, laws burdening religion aren't "generally applicable" when they treat religious conduct less favorably than comparable secular conduct. But they also relied on controversial claims that religious gatherings were comparable to places like grocery stores in their likelihood of spreading the virus. This article offers a different perspective. In addition to the rule about comparators, general applicability also contains a second rule. Where a law requires officials to consider the religious reasons for conduct as a precondition for regulating it, the law isn't generally applicable and ought to be subject to heightened scrutiny. The Court mostly passed over that requirement in the COVID-19 church-closure cases. But rightly understood, it may have provided an alternative path for resolving them-and one that didn't depend on controversial comparisons between churches and shopping centers. Instead, focusing on this second aspect of general applicability would have yielded a commonsense conclusion: where a law or policy grants favored treatment for activities it explicitly deems "essential," "critical," or "life-sustaining," one of those things must be religion, absent compelling reason to the contrary. And understanding the rationale behind that conclusion provides important insights about the meaning of the Free Exercise Clause and several other issues at the heart of the First Amendment.
\end{abstract}

Keywords: free exercise of religion; general applicability; religious neutrality; religious discrimination; religious exemptions; COVID-19 and churches; first amendment; religious liberty

\section{Introduction}

The Free Exercise Clause is controversial, and the Supreme Court's recent cases involving COVID-19 restrictions on worship are no exception. Starting roughly three months after the start of statewide lockdowns, the Court began receiving requests for emergency relief from churches and synagogues on its so-called "shadow docket." ${ }^{1}$ These litigants argued that various restrictions on religious gatherings throughout the states violated the Free Exercise Clause, since many other entities-especially businesses-were subject to less rigorous rules involving occupancy caps or the availability of indoor activities.

In a series of early cases, the Court denied these requests, with Chief Justice Roberts voting with the more progressive justices over several vocal dissents. ${ }^{2}$ But the tide turned

\footnotetext{
${ }^{1}$ See William Baude, Foreword: The Supreme Court's Shadow Docket, 9 N.Y.U. Journal of LaW \& LiberTy 1, 5 (2015) (explaining that the "shadow docket" refers to the Court's orders docket-as opposed to its merits docket-where requests for emergency relief and other matters are decided).

${ }^{2}$ See South Bay Pentecostal Church v. Newsom, 140 S. Ct. 1613 (2020); Calvary Chapel Dayton Valley v. Sisolak, 140 S. Ct. 2603 (2020); Danville Christian Academy v. Beshear, 141 S. Ct. 527 (2020).

(C) The Author(s), 2022. Published by Cambridge University Press on behalf of the Center for the Study of Law and Religion at Emory University. This is an Open Access article, distributed under the terms of the Creative Commons Attribution licence (https://creativecommons.org/licenses/by/4.0/), which permits unrestricted re-use, distribution, and reproduction in any medium, provided the original work is properly cited.
} 
when Justice Amy Coney Barrett replaced Justice Ruth Bader Ginsburg. In Roman Catholic Diocese of Brooklyn v. Cuomo, a new majority composed of the four past dissenters plus Justice Barrett voted to grant emergency relief to Catholic and Jewish claimants who challenged COVID-19-related restrictions on worship in New York City. ${ }^{3}$ And that same trend continued in several later cases involving restrictions in other states, now over dissents by the progressive justices. ${ }^{4}$

In Tandon $v$. Newsom, the Court offered a more detailed explanation for its conclusions. ${ }^{5}$ According to the Court, the Free Exercise Clause requires heightened scrutiny when the government treats "any. . . secular activity" more favorably than religious activity posing a comparable threat to the governmental interests underlying a restriction. ${ }^{6}$ Thus, states like New York and California had violated the Constitution by restricting religious gatherings while allowing people to gather at supermarkets and department stores-activities that, according to the majority, were just as likely to undermine the state's interest in preventing infections.

By focusing on comparative risk, the Court chose to resolve the COVID-19 church-closure cases using a specific aspect of its free exercise doctrine. In Employment Division v. Smith, the Court held that if a law burdening religious practice isn't both neutral and generally applicable, it must be subject to strict scrutiny. ${ }^{7}$ In the church-closure cases, the Court focused most of its attention on the latter requirement-general applicability. But even more than this, it chose to focus on a specific strand of general applicability involving comparators: has the government denied exemptions for religious conduct while granting them to "secular conduct that undermines the government's asserted interests in a similar way"? As I explain below, that inquiry has many important uses. But in the church-closure cases, technical questions about disease transmission made it especially difficult to apply. Is a gathering of 100 people masked and distanced in a church more likely to spread disease than are 100 employees working and sometimes shouting in a meatpacking plant? Would the answer change if many of the workers were improperly masked, or if the church limited its services to thirty minutes, or both?

Given these complications, it's unsurprising that these cases further aggravated an already politicized debate about the Free Exercise Clause. According to Erwin Chemerinsky, the Court's turnabout in Diocese of Brooklyn revealed the new majority to be "activist conservative justices" willing to ignore both evidence and precedent when it suits their purpose. ${ }^{9}$ Professors Laurence Tribe and Michael Dorf went even further, arguing that after the church-closure cases, the Court now looks like "the highest judicial authority of a place called Gilead-the theocratic and misogynist country of Margaret Atwood's dystopian 'The Handmaid's Tale." 10 And indeed, even defenders of decisions like Diocese of Brooklyn tend to describe them as heterodox, not a faithful application of the Court's precedents. ${ }^{11}$

\footnotetext{
${ }^{3} 141$ S. Ct. 63 (2020).

${ }^{4}$ See High Plains Harvest Church v. Polis, 141 S. Ct. 527 (2020); South Bay United Pentecostal Church v. Newsom, 141 S. Ct. 716 (2021); Harvest Rock Church, Inc. v. Newsom, 141 S. Ct. 1289 (2021); Gateway City Church v. Newsom, 141 S. Ct. 1460 (2021); Tandon v. Newsom, 141 S. Ct. 1294 (2021).

${ }^{5} 141$ S. Ct. 1294 (2021).

${ }^{6}$ Id. at 1296.

${ }^{7} 494$ U.S. 872, 879 (1990).

${ }^{8}$ Fulton v. City of Philadelphia, 141 S. Ct. 1868, 1877 (2021) (citing Church of the Lukumi Babalu Aye v. City of Hialeah, 508 U.S. 520, 542-46 (1993)).

${ }^{9}$ Erwin Chemerinsky, In Its COVID Ruling, Trump's Activist Supreme Court Gives Us a Preview of What's to Come, L.A. Times, Nov. 27, 2020, https://www.latimes.com/opinion/story/2020-11-27/op-ed-in-its-covid-ruling-trumps-activist-supreme-court-gave-us-a-preview-of-whats-to-come.

${ }^{10}$ Laurence H. Tribe \& Michael C. Dorf, To this Supreme Court, Religious Freedom Trumps Public Health-Even Amid COVID-19 Plague, U.S.A. TodAy, Nov. 29, 2020, https://www.usatoday.com/story/opinion/2020/11/29/religiousrights-trump-covid-illness-deaths-supreme-court-column/6436196002/.

${ }^{11}$ Josh Blackman, The "Essential" Free Exercise Clause, 4 Harvard Journal of LaW \& Public Policy 637, 695 (2021) (expressing agreement with justices who argued for heightened scrutiny in the COVID-19 church-closure cases,
} 
But what if there's more to the story? What if there was another way to think about the COVID-19 church-closure cases-and one that might have sidestepped the difficult questions about comparative risk?

In what follows, I argue in favor of that possibility. More specifically, I argue that although the Court chose to focus on the question of secular comparators, that wasn't the only option. In fact, there's also another strand of general applicability that could have played a role-one that the Court has already recognized, and one that doesn't depend on comparisons at all. And understanding that point has larger implications for the meaning of the Free Exercise Clause.

At its heart, the requirement of general applicability ensures that government is applying its rules evenhandedly, not in a way that depends on negative value judgments about religion. And often, the most obvious way to enforce that rule will involve asking about secular comparators. Has the government granted exemptions for secular conduct while refusing exemptions for similarly situated religious conduct-say, by allowing police officers to grow beards for medical reasons but not religious ones? ${ }^{12}$ If the difference in treatment isn't traceable to a difference in circumstance, there's good reason to think government has made a value judgment that medical beards are more important than religious ones. But in fact, this isn't the only aspect of general applicability. As the Court's precedents have long suggested, government also engages in the same kind of implicit discrimination where a law or policy offers exemptions based on a value-laden standard while failing to exempt religion.

Consider just a few examples. Imagine a law that forbids animal killings except those that are "necessary." Where a law like that is applied to prohibit religious sacrifices, government hasn't acted without regard to religion. Rather, it has "devalue[d] religious reasons for killing by judging them to be of lesser import" than killings the state deems truly "necessary."13 Likewise, where a law explicitly provides exemptions for conduct deemed "good cause" but religious conduct doesn't qualify, it's clear the government hasn't acted in a religion-blind way. ${ }^{14}$ Instead, a law like that explicitly requires officials to consider religious reasons and find them wanting if the law is to apply at all.

These rules are well established in the Court's case law, and they yield a simple principle. Where a law or policy formally requires officials to make a subjective or value-based judgment about the reasons for conduct in order to regulate it, the law is neither neutral nor generally applicable. Instead, it requires officials to render a negative value judgment about religion as a precondition of the law's enforcement. And once that point is clear, it becomes apparent that many of the COVID-19 church-closure cases could have been resolved by another route-and one that had nothing to do with comparisons between churches and grocery stores.

In regulating worship and related activities, many COVID-19-related restrictions around the country-including those considered by the Court-explicitly distinguished between "essential" and "nonessential" activities, and placed greater restrictions on religion only after deeming it to fall in the latter category. Like the examples above, those regulations by their terms indicated that officials placed additional restrictions on worship only after

but expressing doubt that "this approach is required by Smith"); see also Kathleen A. Brady, COVID-19 and Restrictions on Religious Worship: From Nondiscrimination to Church Autonomy, 2021 Fides et LiberATEs 23, 30 (2021) (arguing that the Court's decision in Diocese of Brooklyn was correct, but that the Court "did not acknowledge its shift" away from prior precedents "or the principle or doctrine that could explain it").

${ }^{12}$ See, e.g., Fraternal Order of Police Newark Lodge No. 12 v. Newark, 170 F.3d 359 (3d Cir. 1999). For a more detailed description of this case and its significance for the general applicability requirement, see infra note 36 and accompanying text.

${ }^{13}$ Lukumi, 508 U.S. at 537.

${ }^{14}$ See Sherbert v. Verner, 374 U.S. 398, 401 (1963) (noting that South Carolina's unemployment laws forbade awarding benefits where a claimant refused work "without good cause" (quoting S.C. Code. Tit. 68-114(3))); see also Lukumi, 508 U.S. at 537 (discussing this law). 
concluding that gathering for religious reasons didn't qualify as "essential," "critical," or "life-sustaining." To be sure, in reaching those conclusions, officials likely considered a variety of factors-the risk of virus transmission, the economic health of the community, and so on. But none of that can hide the fact that, on their face, these regulations also explicitly focused on the worth of various activities, and thus ratcheted up regulation on worship only after making a negative judgment about its value. Scholars and judges have long debated the rightness or wrongness of the Court's decision in Smith. ${ }^{15}$ But if the Free Exercise Clause under Smith means anything, it must mean at least this much: Where government creates carve-outs for conduct it explicitly deems "necessary," "good cause," or "essential," one of those things must be religion, absent a compelling justification to the contrary.

Understanding this aspect of general applicability provides a new framing for many of the COVID-19 church-closure cases, and one that arguably tracks the fundamental concerns underlying them. But it also has larger implications. Most notably, the rule about valuebased distinctions also sheds light on the scope of religious discrimination prohibited under the Free Exercise Clause, and the relationship between the Clause and various other kinds of constitutional protections.

\section{The Church-Closure Cases and the Problem of Secular Comparators}

Under the Court's free exercise doctrine, laws burdening religion must be both neutral and generally applicable. Those are distinct requirements, each with their own content. According to the Court, government "fails to act neutrally when it proceeds in a manner intolerant of religious beliefs or restricts practices because of their religious nature."16 But even where a law burdening religion is formally neutral, it must still be generally applicable. One important aspect of this requirement involves questions of comparison: has the government refused exemptions for religious conduct while granting them to secular conduct that similarly undermines its interest? But in the church-closure cases, that inquiry proved to be particularly difficult.

\section{The Cases in Brief}

Early in the pandemic, the Supreme Court exhibited a deferential attitude toward COVID-19related restrictions on worship. In South Bay United Pentecostal Church v. Newsom, the Court voted 5-4 to reject a church's request to enjoin enforcement of COVID-19-related restrictions in California, which had imposed a stringent occupancy cap on worship that didn't apply to many secular businesses. ${ }^{17}$

The Court didn't issue a written opinion in South Bay. But a concurrence by Chief Justice Roberts focused the constitutional analysis squarely on comparative risk. According to Chief Justice Roberts, California's restriction didn't violate the Free Exercise Clause because the state had applied "similar or more severe restrictions ... to comparable secular gatherings," where people "gather in close proximity for extended periods of time." ${ }^{18}$

Justice Kavanaugh dissented in South Bay along with Justices Thomas and Gorsuch. ${ }^{19}$ These justices didn't contest the idea that the key question was whether California's restrictions treated worship worse than other "comparable" gatherings. But they took issue with Chief Justice Roberts's view that worship services were meaningfully different from places

\footnotetext{
${ }^{15}$ For the purposes of this article, I set aside whether Smith was correctly decided as a matter of first principles. Instead, I assume the framework that Smith laid out and ask what it might entail.

${ }^{16}$ Fulton v. City of Philadelphia, 141 S. Ct. 1868, 1877 (2021).

17140 S. Ct. 1613 (2020).

${ }^{18}$ Id. (Roberts, J., concurring).

${ }^{19}$ Id. at 1615 (Kavanaugh, J., dissenting).
} 
like shopping malls, factories, and cannabis dispensaries in terms of risk. "Assuming all the same precautions are taken," the dissenters pressed, "why can someone safely walk down a grocery store aisle but not a pew?"20

As a one-justice concurrence, Chief Justice Roberts's opinion in South Bay wasn't technically binding on lower courts. But most courts took it as a signal and acted accordingly, concluding that more stringent restrictions on worship were permissible because-unlike other activities-a generic worship service typically involves people singing and chanting in a confined space for extended periods of time. ${ }^{21}$ And with the Supreme Court's rejection of a challenge to Nevada's restrictions on worship a few weeks later, that approach seemed well cemented. ${ }^{22}$

Things changed in Roman Catholic Diocese of Brooklyn v. Cuomo. ${ }^{23}$ There, Catholic and Jewish claimants challenged restrictions on worship in certain parts of New York City. In a Red Zone, houses of worship were limited to a 25 percent occupancy cap or ten people, "whichever is fewer." ${ }^{24}$ Restrictions in Orange Zones imposed a similar twenty-five-person cap. ${ }^{25}$ But in each of these zones, businesses and gatherings designated "essential" faced no such restrictions. ${ }^{26}$

Here unlike the prior church-closure cases, the Court issued an emergency injunction prohibiting enforcement of the restrictions. ${ }^{27}$ The contrast with South Bay was striking. Rather than citing generalized differences between worship and other gatherings, the Court noted that "[t]he Governor . . . stated that factories and schools have contributed to the spread of COVID-19," yet treated those entities less harshly than the Catholic and Jewish claimants who had "admirable safety records." ${ }^{28}$ Likewise, the Court expressed skepticism that a difference in risk could justify the differential treatment: "[A] large store in Brooklyn. . . could have literally hundreds of people shopping there on any given day," yet a "nearby church ... would be prohibited from allowing more than 10 or 25 people inside for a worship service." 29

The Court's opinion in Diocese of Brooklyn was per curiam, so it didn't identify an author or indicate which justices had supported it. But the accompanying concurrences and dissents revealed the vote had been 5-4, and that the new majority was composed of the prior dissenters in South Bay plus Justice Amy Coney Barrett, who had replaced Justice Ruth Bader Ginsburg just one month before. ${ }^{30}$ And after Diocese of Brooklyn, the Court enjoined officials in other jurisdictions from enforcing similar restrictions on worship, often exhibiting the same 5-4 split. $^{31}$

The debate in the church-closure cases was bitter. In Diocese of Brooklyn, Justice Gorsuch implied the dissenting justices were "shelter[ing] in place when the Constitution is under

\footnotetext{
${ }^{20} \mathrm{Id}$.

${ }^{21}$ See Blackman, supra note 11, at 4 (noting that following South Bay "more than one hundred judges would rely on Chief Justice Roberts's opinion").

${ }^{22}$ Calvary Chapel Dayton Valley v. Sisolak, 140 S. Ct. 2603 (2021).

${ }^{23} 141$ S. Ct. 63 (2021).

${ }^{24}$ N.Y. Exec. Order 202.68 (Oct. 6, 2020), 9 N. Y. C. R. R. 8.202.68.

${ }^{25} \mathrm{Id}$;; see also Diocese of Brooklyn, $141 \mathrm{~S}$. Ct. at 65-66.

${ }^{26}$ Id. at 63, 66; see also infra notes 93-103 and accompanying text (explaining New York's regulations in more detail).

${ }^{27}$ Diocese of Brooklyn, 141 S. Ct. at 69.

${ }^{28} \mathrm{Id}$. at 67.

${ }^{29}$ Id. (internal quotation marks omitted).

${ }^{30}$ See id. at 69-81. This majority also included Justice Alito, who had voted to grant emergency relief in South Bay though he did not formally join the South Bay dissent.

${ }^{31}$ See supra note 4 (collecting cases). During the COVID-19 pandemic, courts in other parts of the world also adjudicated similar challenges. For some helpful analysis of these decisions, see Justin Collings \& Stephanie Hall Barclay, Taking Justification Seriously: Proportionality, Strict Scrutiny, and the Substance of Religious Liberty, Boston ColLEGE LAW REVIEW (forthcoming 2022) (manuscript at 27-31, 36-44) (on file with author): Mark L. Movsesian, Law, Religion, and the COVID-19 Crisis, 37 Journal of LaW \& Religion (this issue).
} 
attack." ${ }^{32}$ In a later case, Justice Kagan retorted that the majority was engaged in "armchair epidemiology" rather than a reasonable reading of the Free Exercise Clause. ${ }^{33}$ But more fundamentally, these cases pointed to a bigger puzzle in the Court's jurisprudence.

\section{Secular Comparators}

In the early church-closure cases like South Bay, the Court didn't explain how its analysis tracked the requirements of neutrality and general applicability. But by focusing almost exclusively on whether worship services were "comparable" to less-regulated activities, it was clear the Court was invoking the general applicability requirement-and more specifically, the strand of general applicability focused on secular comparators. In the context of the church-closure cases, though, analyzing that issue proved extremely difficult.

Begin with the basic rule. As Douglas Laycock and Steven Collis have aptly said, general applicability is exactly what it sounds like-a requirement that a law or policy "applies to everybody, in all similar situations-or at least to nearly everybody and nearly all similar situations." ${ }^{34}$ And as the Court has explained, one obvious way to enforce that requirement involves secular comparators. On this understanding, a law fails the general applicability requirement where it refuses an exemption for religious conduct while granting one to "secular conduct that undermines the government's asserted interests in a similar way."35 The reason should be obvious: if religious and secular conduct are similarly situated in terms of the government's interests, granting a secular exemption but denying a religious one isn't traceable to a difference in circumstance. Instead, it reflects a negative value judgment about religion.

To illustrate the point, consider just one well-known example. Imagine a police department has a policy prohibiting facial hair, in order to give its officers a uniform appearance that's easy for the public to recognize. The policy contains no explicit exceptions or discretionary language. But as a matter of practice, the department allows some officers to grow beards for medical reasons but refuses to allow beards for religious reasons. Has the government acted without regard for religion? No, because the policy isn't generally applicable. Exemptions for medical beards and religious beards both undermine the government's asserted interest in officer uniformity. As a result, choosing to grant one exemption but not the other isn't traceable to a difference in circumstance. Instead, it reflects an official judgment that growing beards for medical reasons is more important than growing them for religious reasons. And by making a judgment like that, government has devalued religion in a way the Free Exercise Clause forbids. ${ }^{36}$

Here, though, it's worth noting an important complication. Some courts and scholars have insisted that, contrary to the description above, a law is still generally applicable even if government has denied a religious exemption while granting one for a similarly situated secular activity. On this view, the general applicability rule mandates heightened scrutiny only where a law or policy is so riddled with exceptions that it provides clear evidence of "something more sinister"-namely, raw religious animus. ${ }^{37}$

\footnotetext{
${ }^{32} 141$ S. Ct. 63, 71 (2021) (Gorsuch, J., concurring).

${ }^{33}$ South Bay United Pentecostal Church v. Newsom, 141 S. Ct. 716, 723 (2021) (Kagan, J., dissenting).

${ }^{34}$ Douglas Laycock \& Steven T. Collis, Generally Applicable Law and the Free Exercise of Religion, 95 NeBRASKA LAW REVIEW 1,9 (2016).

${ }^{35}$ Fulton v. City of Philadelphia, 141 S. Ct. 1868, 1877 (2021) (citing Church of the Lukumi Babalu Aye v. City of Hialeah, 508 U.S. 520, 542-46 (1993)).

${ }^{36}$ See Fraternal Order of Police Newark Lodge No. 12 v. Newark, 170 F.3d 359 (3rd Cir. 1999) (opinion of Alito, J.) (holding the actions described above violated the Free Exercise Clause).

${ }^{37}$ See, e.g., Thomas v. Anchorage Equal Rights Commission, 165 F.3d 692, 701-02 (9th Cir. 1999) ("Underinclusiveness is not in and of itself a talisman of constitutional infirmity; rather, it is significant only insofar as it indicates something more sinister."); Chabad Lubavitch of Litchfield City v. Borough of Litchfield, 853 F. Supp. 2d 214, 223 (D. Conn. 2012) ("The fact that a law contains particular exceptions does not cause the law
} 
Prior to the church-closure cases, the Court hadn't spoken to this issue directly. But in Tandon v. Newsom, the Court offered two clarifications relevant to this debate. ${ }^{38}$ First, it said that when inquiring whether two activities are "comparable" for purposes of general applicability, what matters is "the asserted government interest that justifies the regulation at issue." 39 But second and more notably, the Court said that a law doesn't qualify as generally applicable just because it "treats some... activities as poorly as. . . religious exercise." ${ }^{40}$ Instead, general applicability is lacking whenever government treats "any comparable secular activity more favorably than religious exercise"-that is, when it refuses to exempt religious conduct but exempts secular conduct that undermines its interest in a similar way. ${ }^{41}$

In scholarly terms, Tandon signaled a setback for the animus interpretation of general applicability and a victory for what has been called the "most-favored nation" theory. ${ }^{42}$ That theory argues that under the First Amendment, religious conduct must be treated at least as well as preferred secular conduct in terms of exemptions where the government's interest in restricting both is roughly parallel. ${ }^{43}$ Allowing police officers to grow beards for medical reasons but not religious ones may not reflect outright hostility toward Muslims or Sikhs. But judged against the purpose of the no-beard rule, it still signals a devaluing of religion when compared to needs the government considers more important.

Only time will reveal the full significance of Tandon. But even taking the Court at its word about the meaning of the secular comparators inquiry, the COVID-19 church-closure cases also highlighted a difficulty. They showed just how hard it can be to identify which activities are truly "comparable," at least when the underlying controversy relates to highly technical questions like disease transmission.

Consider first the more aggressive stance. In choosing to invalidate many state restrictions on worship, the majority in cases like Diocese of Brooklyn made judgments about the comparative risk of virus transmission in churches versus retail stores. But as to a subject like that, judicial expertise is at its limit. Where the issue is likelihood of infection, deciding whether allowing churches to operate at 50 percent capacity endangers the government's interest "in a similar way" as a 50-percent rule for big box stores requires epidemiological expertise outside the core of judicial competence. ${ }^{44}$ To be sure, the difficulty of that question isn't a reason to avoid it. As one great justice observed long ago, judges in our system are obliged to defend the Constitution "not by authority of [their] competence, but by force

not to be generally applicable, so long as the exceptions are broad, objective categories, and not based on religious animus."). For scholarly arguments along similar lines, see, e.g., Zalman Rothschild, Free Exercise's Lingering Ambiguity, 11 California LaW Review OnLine 282, 284-85 (2020) (arguing that the general applicability requirement is violated only in "the rare circumstance where religion is ... treated differently from all (or at least nearly all) secular activities," giving rise to the inference the law was "gerrymandered with religious practice in mind"); James M. Oleske, Jr., Free Exercise (Dis)honesty, 2019 WISCONSIN LAW REVIEW 689, 729 (arguing that a law qualifies as generally applicable even if it is not consistently applied, so long as the underinclusion "bear[s] no indicia of discriminatory intent"). For a brief response, see Laycock \& Collis, supra note 34, at 25-26.

${ }^{38} 141$ S. Ct. 1294 (2021).

${ }^{39} \mathrm{Id}$. at 1296.

${ }^{40} \mathrm{Id}$.

${ }^{41}$ Id. The Court also repeated that same version of the rule in Fulton. See Fulton v. City of Philadelphia, 141 S. Ct. 1868, 1878 (2021).

${ }^{42}$ See Douglas Laycock, The Remnants of Free Exercise, 1990 Supreme Court Review 1, 49-50 (arguing that, under Smith, "religion get[s] something analogous to most-favored nation status," such that "[r]eligious speech should be treated as well as political speech, religious land uses should be treated as well as any other land use of comparable intensity, and so forth").

${ }^{43}$ See Laycock \& Collis, supra note 34, at 21-22 (arguing that "a single secular exception also triggers strict scrutiny if it undermines the state interest allegedly served by regulating the religious conduct" because "[ $t]$ he constitutional right to free exercise of religion is a right to be treated like the most favored analogous secular conduct").

${ }^{44}$ And indeed, several justices recently highlighted exactly that problem. See Fulton, $141 \mathrm{~S}$. Ct. at 1921-22 (Alito, J., concurring) (observing the difficulties of comparison with respect to the COVID-19 church-closure cases). 
of [their] commissions." ${ }^{45}$ But in a context like the church-closure cases, where the questions arose as requests for emergency relief, the Court's decisions on those technical issues attracted understandable criticism.

But the problem runs the other way too. The justices who dissented in Diocese of Brooklyn and the later church-closure cases focused on the fact that, according to experts, the risk of virus transmission was especially strong in churches and other religious gatherings. But approaching the problem at that level of generality fails to grapple with what made the cases genuinely hard.

To understand the difficulty, think about just a few problems arising from Diocese of Brooklyn, the case about New York's ten-person cap on worship. Imagine the experts say that attending religious worship is one of the "riskiest activities" in terms of transmission, because "[1]arge groups of people enter an enclosed space, then sit or stand near each other for a significant amount of time, and typically talk and sing." ${ }^{46}$ But what if, as the Catholic plaintiffs did, a church reduced its services to less than an hour, eliminated singing, required masks, and spaced attendees significant distances apart-even when entering and leaving the building? ${ }^{47}$ If an average trip to the grocery store takes roughly the same amount of time, involves brushing past other shoppers to grab the cereal or the apples, and may require standing in line behind someone talking loudly to their spouse, is it really so obvious that the government is acting evenhandedly by imposing a ten-person cap on one activity but not the other?

Likewise, imagine the government claims that some religious groups are ignoring safety requirements like masks or distancing-here, the city's Orthodox Jews-so it decides to place special across-the-board attendance caps on worship. ${ }^{48}$ If similar violations are discovered elsewhere-say, in restaurants serving alcohol ${ }^{49}$-but government opts for retail punishments rather than the same across-the-board restrictions it placed on worship, can that difference be fully justified by technical judgments about risk? Or at the very least, might it also depend on unconfirmed assumptions about what "usually happens" at a Shabbat service or worship services generally? ${ }^{50}$

The answers to these questions, I submit, are not obvious. And indeed, it is precisely because they are not obvious that Diocese of Brooklyn and the other church-closure cases were so divisive. Smith's general applicability prong requires courts to ask whether the government is actually treating religious conduct the same as nonreligious conduct posing a similar threat. But in the church-closure cases, that task involved an assessment of technical evidence susceptible to different readings depending on whether one focused on the claimants themselves or imagined generic conduct.

\footnotetext{
${ }^{45}$ West Virginia State Board of Education v. Barnette, 319 U.S. 624, 640 (1943) (opinion of Jackson, J.).

${ }^{46}$ Brief of the American Medical Association as Amicus Curiae at 6, Roman Catholic Diocese of Brooklyn v. Cuomo, 141 S. Ct. 63 (2020) (No. 20A87).

${ }^{47}$ See Record of Roman Catholic Diocese, Exhibit O at III 3-4 (documenting the reduced length of the Diocese's services); Exhibit N at III 10-13 (documenting that the church "took specific steps" to eliminate singing by removing hymnal books from pews and prohibiting choirs in all worship services); Exhibit D, 16:3-18:2 (documenting masking and social distancing requirements as well as reduced capacity limits).

${ }^{48}$ See Emergency Application for Writ of Injunction at 6-7, 10-11, Agudath Israel of America v. Cuomo, $141 \mathrm{~S}$. Ct. 63 (2020) (No. 20A90) (quoting Governor Cuomo's claims that the city's recent COVID-19 cluster was "predominately an ultra-orthodox cluster," and that the main source of the problem was the "ultra-Orthodox community").

${ }^{49}$ See Governor Cuomo Announces 21 Additional Bar and Restaurants' Liquor Licenses Suspended for Egregious Violations of Coronavirus-Related Regulations (Oct. 23, 2020), https://www.governor.ny.gov/news/governor-cuomo-announces-21additional-bar-and-restaurants-liquor-licenses-suspended-egregious.

${ }^{50}$ See J. David Goodman, et al., 9 Top N.Y. Health Officials Have Quit as Cuomo Scorns Expertise, N.Y. Times, February 1, 2021, https://www.nytimes.com/2021/02/01/nyregion/cuomo-health-department-officials-quit.html (last updated September 23, 2021) (reporting that "state health officials said they often found out about major changes in pandemic policy only after Mr. Cuomo announced them at news conferences-and then asked them to match their health guidance to the announcements," and that "the State Health Department was not deeply involved in final decisions" regarding the "microclusters" at issue in Diocese of Brooklyn).
} 
These problems probably can't be solved entirely, either in cases involving COVID-19 or in others presenting similar difficulties. Smith and its general applicability requirement are the law (at least for now), ${ }^{51}$ so inquiries into comparative harm will often be a part of the framework. But even recognizing that, one might still wonder if there was another way to approach the problem.

\section{General Applicability and Religion-Conscious Regulation}

In the COVID-19 church-closure cases, the Court focused largely on the issue of secular comparators. This Part suggests that another route was available. It begins by explaining another aspect of general applicability-this one focused on laws offering exemptions based on subjective or value-laden criteria. It goes on to argue that, properly understood, this aspect of general applicability offered an alternative theory for resolving many of the church-closure cases-and one that had little to do with comparisons between churches and grocery stores.

\section{The Other Side of General Applicability}

As mentioned above, general applicability is more or less exactly what it sounds like: a requirement that laws apply across the board and treat similarly situated people and activities the same. In the free exercise context, that requirement has several purposes. One purpose is to provide vicarious protection for religious minorities, by tying their rights to those of the majority. It ensures that, as Justice Robert Jackson famously said, "the principles of law which officials would impose upon a minority must be imposed generally." 52 But another purpose-and perhaps the more prominent one-is to identify instances of nonobvious bias or selective indifference toward religion, even if the law itself is facially neutral. ${ }^{53}$ Requiring that laws burdening religion be generally applicable is a way of ensuring that government is applying its rules even-handedly, and not in a way that treats religion with less solicitude than other similarly situated activities.

But how exactly does this requirement work? As discussed above, one aspect of general applicability-perhaps the most prominent one-focuses on comparison. Has the government refused religious exemptions while granting them to secular conduct that "undermines the government's asserted interests" in a similar way? ${ }^{54}$ But in fact, that's not the whole universe. General applicability also has another aspect. To see it, though, the first step is to return to the Court's decision in Smith.

In Smith, the Court considered free exercise claims brought by two workers who were denied unemployment benefits after they were fired for using peyote in a Native American religious ceremony. The Court said the Free Exercise Clause did not require an exemption because Oregon's ban on peyote was neutral and generally applicable. And according to Justice Scalia, that had always been the law-the Court "ha[d] never held that an individual's religious beliefs excuse him from compliance with an otherwise valid law." 55 In so insisting, however, the Court had to distinguish several past cases that

\footnotetext{
${ }^{51}$ In Fulton the Court declined to overrule Smith. But no fewer than six justices have openly expressed dissatisfaction with Smith, suggesting that it may be overruled in the future. See Fulton v. City of Philadelphia, $141 \mathrm{~S}$. Ct. 1868, 1882 (2021) (Barrett, J., concurring); id. at 1883 (Alito, J., concurring).

${ }^{52}$ Railway Express Agency v. New York, 336 U.S. 106, 112 (1949) (Jackson, J., concurring); see also Laycock \& Collis, supra note 34, at 24-26 (discussing this justification). Commentators have also picked up on this aspect of general applicability in the context of the church-closure cases specifically. See Cass R. Sunstein, Our Anti-Korematsu, American Journal of LaW \& Inequality 221, 232-34 (2021).

${ }^{53}$ For another recent exploration of these justifications and others, see Nelson Tebbe, The Principle and Politics of Equal Value, 121 Columbia LaW Review 2397, 2438-48 (2021).

${ }^{54}$ Fulton, 141 S. Ct. at 1877 (citing Church of the Lukumi Babalu Aye v. City of Hialeah, 508 U.S. 520, 542-46 (1993)).

${ }^{55}$ Employment Division v. Smith, 494 U.S. 872, 878-79 (1990).
} 
suggested the opposite. In Sherbert v. Verner, the Court had held that the Free Exercise Clause forbade a state from requiring a claimant seeking unemployment benefits to work on Saturday where her religion observed that day as a Sabbath. ${ }^{56}$ The Court reasoned that forcing her to choose between receiving benefits and violating her faith was equivalent to imposing a "fine... for her Saturday worship." ${ }^{57}$ And a series of later unemployment cases said the same thing. ${ }^{58}$

The Court in Smith dealt with this problem by arguing that-unlike Oregon's "across-the-board" ban on peyote-the laws in these unemployment cases were not generally applicable. ${ }^{59}$ Rather, they involved a "system of individual exemptions" that "invite[d] consideration of the particular circumstances" behind each claimant's conduct. ${ }^{60}$ So in Sherbert, for example, the problem wasn't that the law had forced Adell Sherbert to choose between observing her Sabbath or receiving benefits. Rather, the problem was that the law didn't actually impose a blanket requirement that claimants work on Saturday. Instead, it allowed officials to enforce or ignore the rule based on an "individualized. . . assessment of the reasons" for each applicant's refusal-and more specifically, based on an assessment of whether a claimant's refusal was justified by "good cause." ${ }^{61}$ And in a situation like that, the Court said, denying exemptions for religious claimants required heightened scrutiny.

Smith's discussion of the unemployment cases gave significant content to the general applicability requirement by focusing on laws that grant unbridled discretion to enforcement authorities. And, fittingly, commentators and courts have often viewed Sherbert in those terms, asking whether the government has created a system of entirely discretionary exemptions. ${ }^{62}$ It was that aspect of Sherbert, for instance, that the Supreme Court relied on in Fulton v. City of Philadelphia. ${ }^{63}$

In Fulton, the Supreme Court held that the Free Exercise Clause forbade Philadelphia from terminating a foster-care contract with Catholic Social Services because the agency declined to place children with same-sex couples. ${ }^{64}$ To reach that conclusion, the Court held that Philadelphia's nondiscrimination policy in its foster care contracts was not generally applicable, since it allowed a city official to grant exemptions "in his/her sole discretion." ${ }^{65}$ Citing Sherbert, the Court said that this "formal system of entirely discretionary exemptions" triggered heightened scrutiny, regardless of whether any exemptions had actually been granted. ${ }^{66}$

Fulton focused on the discretion that Philadelphia's law delegated to enforcement officials. But in fact, this isn't the only lesson to draw from Sherbert and the other unemployment cases. As the Court has repeatedly suggested, those cases also contain a second lesson-

\footnotetext{
56374 U.S. 398 (1963).

${ }^{57}$ Id. at 404.

${ }^{58}$ See Thomas v. Review Board, 450 U.S. 707 (1981); Hobbie v. Unemployment Appeals Commission, 480 U.S. 136 (1987); Frazee v. Illinois Department of Employment Security, 489 U.S. 829 (1989).

${ }^{59}$ Smith, 494 U.S. at $884-85$.

${ }^{60} \mathrm{Id}$. at 884 .

${ }^{61} \mathrm{Id}$.

${ }^{62}$ See, e.g., Laycock \& Collis, supra note 34, at 10-11 (treating Sherbert as an expression of the general applicability requirement); Richard F. Duncan, Free Exercise and Individualized Exemptions: Herein Smith, Sherbert, Hogwarts, and Religious Liberty, 83 Nebraska LaW Review 1178, 1186-90 (2005) (same); Alan Brownstein, Protecting Religious Liberty: The False Messiahs of Free Speech Doctrine \& Formal Neutrality, 18 Journal of LAW \& Politics 119, 193-94 (2002) (describing Sherbert as "limited to those situations where the state provides the officials, charged with administering and enforcing a law, with substantially unguided discretion in determining how and against whom the law will be enforced"). For some examples from the lower courts applying this aspect of Sherbert, see Ward v. Polite, 667 F.3d 727, 738-40 (6th Cir. 2012); Axon-Flynn v. Johnson, 356 F.3d 1277 (10th Cir. 2004); and Rader v. Johnston, 924 F. Supp. 1540 (D. Neb. 1996).

${ }^{63} 141$ S. Ct. 1868 (2021).

${ }^{64} \mathrm{Id}$. at 1882.

${ }^{65} \mathrm{Id}$. at 1878 .

${ }^{66} \mathrm{Id}$. at $1878-79$.
} 
this one involving not unfettered discretion, but instead something else that's just as common. To see it, consider just a few other precedents.

In Church of the Lukumi Babalu Aye, Inc. v. City of Hialeah, the Court examined a series of city ordinances that, each in different ways, banned animal sacrifice-the primary ritual of a religion called Santeria. ${ }^{67}$ The Court enjoined enforcement of the ordinances, in part because they seemed designed to suppress Santeria sacrifice. ${ }^{68}$ Yet in its discussion, the Court also identified an additional problem. Besides the ordinances mentioned above, the city had also adopted the state's generic animal cruelty statute, which imposed punishment for anyone who "unnecessarily. . . kills any animal." ${ }^{\circ 9}$ Unlike the other ordinances, this law didn't mention "sacrifice" or contain a labyrinth of explicit qualifications for favored activities (though at argument, the city said it wouldn't apply the law to things like hunting or pest control).$^{70}$ Unlike the other ordinances, nothing on the face of this law mentioned religion or religious practices specifically. Fittingly, the city contended that it was "the epitome of a neutral prohibition." ${ }^{71}$ Yet according to the Court, that was not so.

The Court began by noting that, because the law explicitly prohibited only "unnecessary" killings, it "require[d] an evaluation of the particular justification for the killing," and thus created a "system of individualized governmental assessment" just like the law in Sherbert. ${ }^{72}$ Moreover, the Court continued, by interpreting that law as applying to religious sacrifice, the government's "application of the ... test of necessity devalue[d] religious reasons for killing, by judging them to be of lesser import than nonreligious reasons." ${ }^{73}$ The law banning unnecessary animal killings didn't explicitly target religious sacrifice. And, at least arguably, it didn't delegate unbridled discretion to enforcement authorities the way a "good cause" exception does. But according to the Court, that was beside the point. By its terms, this law still required officials to examine the reasons behind each party's act of killing to determine whether such killing was "necessary." And when applied against religion, a law employing that kind of subjective or value-based differentiation wasn't neutral or generally applicable. Rather, it "devalue[d]" religion by explicitly requiring officials to declare sacrifice "unnecessary" as a precondition to regulating it. ${ }^{74}$ Thus, the Court concluded, the application of this law also "singled out religious practice for discriminatory treatment" and required heightened scrutiny. ${ }^{75}$

At this point, it's important to note the difference between the Court's treatment of the Sherbert-style cases in Lukumi as compared to its original treatment of the issue in Smith. In Smith, the Court described Sherbert and its progeny as cases involving laws that explicitly granted officials broad discretion to give or deny exemptions. ${ }^{76}$ But in Lukumi, the Court focused on a different problem. Besides granting wide discretion, the law in Sherbert also explicitly differentiated conduct based on an assessment of the reasons for engaging in it: refusing to work on Saturday was permissible, but only if done for "good cause," just as killing animals in Florida was permissible, but only if it was "necessary." 77 And according to the Court, that textual fact presented a separate, additional concern.

\footnotetext{
${ }^{67} 508$ U.S. 520 (1992).

${ }^{68} \mathrm{Id}$. at 524.

${ }^{69}$ See id. at 537 (citing Fla. Stat. § 828.12 (1987)).

${ }^{70} \mathrm{Id}$.

${ }^{71} \mathrm{Id}$.

${ }^{72} \mathrm{Id}$. at 537 (citation and internal quotation marks omitted).

${ }^{73} \mathrm{Id}$.

${ }^{74} \mathrm{Id}$.

${ }^{75} \mathrm{Id}$. at 538.

${ }^{76}$ See Employment Division v. Smith, 494 U.S. 872, 884-85 (1990); see also Fulton v. City of Philadelphia, 141 S. Ct. 1868,1878 (2021) (discussing this aspect of Sherbert).

${ }^{77}$ See Sherbert v. Verner, 374 U.S. 398, 401 (1963) (noting that South Carolina's unemployment statutes forbid awarding benefits where a claimant refused to accept work "without good cause" (quoting S.C. Code. Tit. 68-114(3))).
} 
By employing categories like "necessary" or "good cause," these laws unambiguously required government to "asses[s] . . the reasons for the . . conduct" in question. ${ }^{78}$ But even more, when used to punish religious conduct, they revealed that government had "devalue[d] religious reasons," because they allowed punishment only after determining that religious motivations didn't qualify as "good cause" or "necessary."79 By regulating an activity contingent on a negative judgment about the religious reasons for undertaking it, these laws discriminated against religion in a way the Free Exercise Clause forbids.

The Court's discussion in Lukumi identified a new aspect of Sherbert and the unemployment cases-this one focused on governmental restrictions that employ subjective or valuebased standards as a condition of their application. And in fact, those aren't the only cases where this rule appears. The Court applied the same rule in Masterpiece Cakeshop v. Colorado Civil Rights Commission, albeit without fully explaining it. ${ }^{80}$

In Masterpiece, the Court held that Colorado violated the Free Exercise Clause by failing to extend the "neutrality that the Constitution requires" to a religious baker who refused to bake a cake for a same-sex wedding. ${ }^{81}$ Commentators have tended to focus on Justice Kennedy's analysis of the statements of a few commissioners as the basis for the decision. ${ }^{82}$ But the more consequential point is what followed.

Prior to the religious baker's case in Masterpiece, the state had excused several other bakers from charges of religious discrimination after they refused to bake cakes with anti-LGBTQ messages for religious customers. ${ }^{83}$ Yet when the religious baker in Masterpiece raised that point, the state court said those refusals were allowed because the secular bakers were simply refusing an "offensive ... requested message." ${ }^{84}$ According to the Supreme Court, however, that explanation was impermissible-the Constitution doesn't allow differential treatment of religion based on "the government's own assessment of offensiveness." 85

Here, the Court wasn't saying that Colorado itself had called the religious anti-LGBTQ messages "offensive," as some interpreters have claimed. ${ }^{86}$ Rather, it was reiterating the same rule about value-based distinctions it already laid out in Lukumi and Sherbert. Where a state creates an exemption from its public accommodations law based on a subjective standard-whether a provider finds a request "offensive"-it may not refuse the same exemption to providers who claim offense based on their religion. Why not? Because doing so devalues religious reasons by "elevat[ing] one view of what is offensive over another"-it suggests that secular reasons for taking offense are worthy of solicitude, but religious reasons are not. $^{87}$

Appreciating this aspect of cases like Lukumi, Sherbert, and Masterpiece adds two additional features to the concept of general applicability beyond those already discussed. First, it provides an added textual requirement. As shown above, the Court has clearly indicated that a law isn't generally applicable where it provides officials wide discretion to give or

\footnotetext{
${ }^{78}$ Lukumi, 508 U.S. at 537 (quoting Smith, 494 U.S. at 884).

${ }^{79} \mathrm{Id}$.

${ }^{80} 138$ S. Ct. 1719 (2018).

${ }^{81} \mathrm{Id}$. at 1724.

${ }^{82}$ See, e.g., Leslie Kendrick \& Micah Schwartzman, The Etiquette of Animus, 132 HaRvard Law Review 133, 138-43, 14648 (2018) (extensively analyzing this aspect of Masterpiece and arguing that the Court treated the case as involving a problem of "adjudicative etiquette").

${ }^{83}$ Masterpiece, 138 S. Ct. at 1728.

${ }^{84}$ See id. at 1731. See also Craig v. Masterpiece Cakeshop, Inc., 370 P.3d 272, 282 n.8 (Colo. App. 2015) (arguing that the religious baker's case "is distinguishable" because the other bakeries "did not refuse the patron's request because of his creed, but rather because of the offensive nature of the requested message").

${ }^{85}$ Masterpiece, 138 S. Ct. at 1731.

${ }^{86}$ See Kendrick \& Schwartzman, supra note 82, at 144-45 (offering this interpretation); Lawrence G. Sager \& Nelson Tebbe, The Reality Principle, 34 Constitutional Commentary 171, 180 (2019) (same).

${ }^{87}$ Masterpiece, 138 S. Ct. at 1731; see also id. (concluding that the state had adjudicated the religious baker's claim "based on a negative normative "evaluation of the particular justification" for his religious objection (quoting Church of the Lukumi Babalu Aye, Inc. v. City of Hiahleah, 508 U.S. 520, 537 (1993))).
} 
withhold exemptions. But on Lukumi's reading, Sherbert and similar cases also established an additional rule-and one that the Court again reiterated in Masterpiece. A law is not generally applicable where it explicitly employs subjective or value-based categories as a basis for differential treatment while also punishing religion. Such laws do more than impose an "incidental" burden on religious practice. ${ }^{88}$ Rather, they explicitly require officials to consider the religious aspect of an activity and render a negative judgment about it as a precondition for regulation. ${ }^{89}$ Applied to religion, these laws are less than generally applicable, because their structure clearly reveals government has taken religion into account and "devalue[d]" it compared to activities it considers truly worthy of exemption. ${ }^{90}$

But there's also a second implication-this one just as important. As has already been mentioned, under the general applicability requirement, courts are often required to ask whether a proposed religious exemption would "endange[r] [the government's] interest in a similar or greater degree" when compared to other conduct eligible for exemption. ${ }^{91}$ The point of that analysis is to smoke out instances in which government actually has devalued religion, even if the text of a law doesn't make it obvious. But notice that, under Lukumi's treatment of cases like Sherbert and also under Masterpiece, that inquiry into comparative harm isn't always necessary.

Where a law has been applied against religious conduct while explicitly indicating it only covers acts lacking "good cause," killings that are "unnecessary," and so on, there's no need to ask whether the government has implicitly considered religion. On the contrary, these laws explicitly require officials to render a negative judgment about the religious aspect of the conduct if the law is to apply at all. Under these laws, a religious claimant's benefits can be refused only after determining that Sabbath observance isn't "good cause," and her animal slaughter can be regulated only after concluding religious sacrifice isn't "necessary." And the same is true of a judge-made rule exempting secular bakers from fulfilling requests they deem "offensive" while refusing to exempt religious bakers who raise the same objection. ${ }^{92}$ In these instances, there's no need to ask about comparative harm to make sure government isn't considering or devaluing religion. The law itself has already told us the opposite is true.

Commentators and courts have sometimes read Sherbert and related cases to be focused on laws explicitly delegating wide discretion. But in fact, those cases aren't so limited. Where a law or policy explicitly requires considering the reasons for conduct while also punishing religion, it fails the general applicability requirement. That kind of law isn't regulating without regard to religion. Instead, it has explicitly made religion part of the calculus and found it wanting. And understanding that point provides a new vantage point for thinking about Diocese of Brooklyn and several of the other COVID-19 church-closure cases.

\section{General Applicability and "Essential” Activities}

In Diocese of Brooklyn and the other church-closure cases, the Court focused almost exclusively on the aspect of general applicability involving comparisons-and more specifically, on comparisons between things like worship services and grocery stores. But in fact, that

\footnotetext{
${ }^{88}$ See Employment Division v. Smith, 494 U.S. 872, 878 (1990) (declaring that government does not "prohibit" free exercise where the burden is "merely the incidental effect of a generally applicable and otherwise valid provision").

${ }^{89}$ See Masterpiece, 138 S. Ct. at 1731 (noting that differential treatment of religion "cannot be based on the government's own assessment of offensiveness," because such a rule "elevates one view of what is offensive over another and itself sends a signal of official disapproval").

${ }^{90}$ Lukumi, 508 U.S. at 537. By focusing on the law as applied, this rule follows the usual pattern of doctrines mandating judicially created religious exemptions. See Stephanie H. Barclay \& Mark L. Rienzi, Constitutional Anomalies or As-Applied Challenges? A Defense of Religious Exemptions, 59 Boston College LaW Review 1595, 1611 (2018) (observing that, generally speaking, "judicially-created religious exemptions are . . a species of as-applied adjudication").

${ }^{91}$ Lukumi, 508 U.S. at 543.

${ }^{92}$ See Masterpiece, 138 S. Ct. at 1731.
} 
wasn't the only route available. Under a more complete understanding of general applicability, many of the church-closure cases could have pursued another avenue, and one that probably should have been relatively uncontroversial.

Begin with Diocese of Brooklyn, the case involving New York's color-coded regulations that marked the shift in the Court's approach. ${ }^{93}$ From the beginning of the pandemic, New York's COVID-19-related rules imposed varying capacity limits on a variety of entities, but provided special privileges to any "essential business or entity providing essential services." 94 State guidance defined an "essential business" as any that "provid[ed] products or services that are required to maintain the health, welfare, and safety of the citizens of New York State." 95 Under that definition, the state had predictably privileged entities like grocery stores and hospitals. But beginning early in the pandemic and continuing into the ensuing months, it also included many other entities-factories, airports, banks, bike shops, liquor stores, acupuncturists, cannabis dispensaries, and hardware stores to name just a few. ${ }^{96}$ Thus, as a matter of law, New York had determined that-in each of those instances-the entities in question provided services "required to maintain the health, welfare, and safety of [its] citizens." 97

The state's early executive orders did not indicate definitively whether religious institutions might qualify as "essential." 98 Eventually, though, the state declared that all worship services were "non-essential gatherings," and that "individuals should not gather in houses of worship, homes, or other locations for religious services until the end of th[e] public health emergency." 99 And that basic distinction continued to operate behind the state's stringent numerical caps on worship in New York City's color-coded zones. ${ }^{100}$

Like the laws in Lukumi, Sherbert, and Masterpiece, New York's COVID-19 mitigation regime explicitly conditioned regulation on a subjective, value-based appraisal. Where a business or gathering was "essential," it was subject to fewer if any restrictions; where it was "nonessential," it was not. Likewise, as in these cases, there's no question that New York chose to regulate religious worship only after determining that gathering for religious reasons was not "required to maintain the health, welfare, and safety" of its citizens, regardless of the precautions houses of worship actually took. ${ }^{101}$

Stating the matter in the Court's preferred terminology, then, New York's regime depended on an "individualized. . . assessment of the reasons" for various gatherings. ${ }^{102}$ But even more than this, by designating worship as "nonessential," New York's regulations

\footnotetext{
93141 S. Ct. 63, 66-67 (2020).

${ }^{94}$ N.Y. Exec. Order 202.6 (Mar. 18, 2020), 9 N. Y. C. R. R. 8.202.6.

${ }^{95}$ See Empire State Business Development Corporation, Frequently Asked Questions for Determining Whether a Business Is Subject to a Workforce Reduction under Recent Executive Order Enacted to Address COVID-19 Outbreak (Mar. 22, 2020), https://esd.ny.gov/sites/default/files/ESD_EssentialEmployerFAQ_032220.pdf.

${ }^{96}$ See N.Y. Exec. Order 202.6, supra note 94; New York State Issued Updated Guidance on Essential (and Non-essential) Businesses, National Law Review (Apr. 9, 2020), https://www.natlawreview.com/article/new-york-state-issues-updatedguidance-essential-and-non-essential-businesses. See also N.Y. Dep't of Health, Novel Coronavirus (COVID-19) Guidance for Registered Organizations (Mar. 17, 2020), https://mjbizdaily.com/wp-content/uploads/2020/03/RO-Covid-19Guidance.pdf (clarifying that cannabis dispensaries participating in the state's medical marijuana program qualified as "essential").

${ }^{97}$ See Empire State Business Development Corp., Frequently Asked Questions, supra note 95.

${ }^{98}$ N.Y. Exec. Order 202.6, supra note 94 (failing to include houses of worship in the list of essential businesses but also stating that "[a]ny other business may be deemed essential” upon request and approval by the governor's office).

${ }^{99}$ Guidance for Determining Whether a Business Enterprise Is Subject to a Workforce Reduction under Recent Executive Orders (Apr. 17, 2020), https://nyscouncil.org/guidance-for-determining-whether-a-business-enterpriseis-subject-to-a-workforce-reduction-under-recent-executive-orders/.

100 See id.; see also N.Y. Exec. Order 202.68, supra note 24; Diocese of Brooklyn v. Cuomo, 141 S. Ct. 63, 66-67 (2020).

${ }^{101}$ See Empire State Business Development Corp, Frequently Asked Questions, supra note 95.

102 Church of the Lukumi Babalu Aye, Inc. v. City of Hialeah, 508 U.S. 520, 537 (1993) (quoting Employment Division v. Smith, 494 U.S. 872, 884 (1990)).
} 
"devalue[d] religious reasons for [gathering] by judging them to be of lesser import than nonreligious reasons" the state deemed truly "essential." ${ }^{103}$ Parallel to Sherbert, Lukumi, and Masterpiece, the regulations explicitly required officials to consider the value of religious gatherings as a precondition for regulation-officials limited worship only after evaluating religious reasons for meeting and finding them wanting. And where religion is regulated under a regime like that, the First Amendment requires heightened scrutiny, irrespective of additional arguments about the similarities or differences between churches and hardware stores.

This aspect of general applicability-and specifically, the rule about regulations employing subjective or value-based categories-provides an explanation for the Court's conclusion in Diocese of Brooklyn that doesn't depend on more controversial claims about comparative harm. And, in fact, this rule also sheds light on other cases too.

Consider Calvary Chapel v. Sisolak, a challenge to Nevada's restrictions on worship that predated Diocese of Brooklyn. ${ }^{104}$ Early in the pandemic, Nevada's governor issued an executive order outlining a list of "Essential services and sectors," which were allowed to remain open without occupancy caps, subject to social distancing requirements. ${ }^{105}$ As in New York, the list included a range of entities such as grocery stores, pharmacies, dry cleaners, and pet shops. ${ }^{106}$ This early order conspicuously declined to label houses of worship "essential." Instead, it simply urged faith leaders to "find ways to tend to your congregation without bringing them together in person." ${ }^{107}$ But in less than a month, the governor changed course, placing a hard ten-person cap on all religious gatherings-even "drive-in and pop-up services." 108

Eventually, Nevada adjusted its restrictions on worship to a hard fifty-person cap while choosing to treat retail stores and casinos more leniently. ${ }^{109}$ At the Supreme Court, the state defended that choice by relying on expert medical advice that worship services presented special risks. ${ }^{110}$ But like New York's restrictions on worship, Nevada's restrictions were also arguably overbroad-they applied the same way regardless of the size of the church, a congregation's specific sanitation procedures, or adjustments to worship services that reduced risk. ${ }^{111}$

Here again, the Court divided on whether churches and other religious institutions were more likely to spread germs than casinos. ${ }^{112}$ But regardless, Nevada's rules ought to have been subject to heightened scrutiny. By their terms, these restrictions provided special

${ }^{103}$ Id. This argument wasn't totally absent from the Court's opinions. In his concurrence in Diocese of Brooklyn, Justice Gorsuch gave special attention to New York's distinction between "essential" and "nonessential" businesses. See Diocese of Brooklyn, 141 S. Ct. at 69 (Gorsuch, J., dissenting) (arguing that, under New York's regulations, "laundry and liquor, travel and tools, [were] all 'essential' while traditional religious exercises [were] not," and insisting "[t]hat is exactly the kind of discrimination the First Amendment forbids").

104140 S. Ct. 2603 (2020).

${ }^{105}$ Nevada Health Response COVID-19 Risk Mitigation Initiative (Mar. 3, 2020), https://gov.nv.gov/uploadedFiles/ govnewnvgov/Content/News/Emergency_Orders/2020_attachments/2020-03-17-NV-Health-Reponse-COVID19-RiskManagement-Initiative-2.pdf.

${ }^{106}$ Id.

${ }^{107}$ Id.

108 COVID-19 Declaration of Emergency Directive 013 (Apr. 8, 2020), https://gov.nv.gov/News/Emergency_Orders/ 2020/2020-04-08_-_COVID-19_Declaration_of_Emergency_Directive_013_(Attachments)/.

109 See COVID-19 Declaration of Emergency Directive 021, § 11 (restrictions on worship); id. at § 20-28 (allowing bowling alleys, restaurants, breweries, and other entities to operate at 50 percent capacity with no per-person limit), https://gov.nv.gov/News/Emergency_Orders/2020/2020-05-28_-_COVID-19_Declaration_of_Emergency_Directive_021_-Phase_Two_Reopening_Plan_(Attachments)/.

${ }^{110}$ Brief of Respondents Steve Sisolak and Aaron D. Ford at 15, Calvary Chapel Dayton Valley v. Sisolak, 140 S. Ct. 2603 (2020) (No. 19A-1070) (insisting that "mass gatherings have a higher risk of COVID-19 transmission than general commerce"); id. at Exhibit 4 (providing opinion of the state's chief medical officer).

${ }^{111}$ See COVID-19 Declaration of Emergency Directive 021, supra note 109, § 11.

${ }^{112}$ See Calvary Chapel Dayton Valley v. Sisolak, 140 S. Ct. 2603 (2020) (Alito, J., dissenting) (pointing out the disparate treatment of churches and casinos); id. at 2609 (Gorsuch, J., dissenting) (same); id. (Kavanaugh, J., dissenting) (same). 
carve-outs for "essential services and sectors." As a result, they explicitly required officials to conclude that houses of worship were "nonessential" as a condition for regulating them more stringently. And under Lukumi, Sherbert, and Masterpiece, a regime like that isn't generally applicable.

To be sure, there are closer cases. For example, what if a law technically places religion on the favored side of a subjective designation like "essential," but without the benefits it provides to other entities in that class? That was the situation in California, whose COVID-19 mitigation restrictions were the subject of the initial challenge in South Bay and numerous other emergency appeals at the Supreme Court.

Early in the pandemic, California issued a directive identifying sixteen "critical infrastructures" that were exempt from stay-at-home requirements and other restrictions. ${ }^{113}$ Notably, these early regulations also classified worship services as "critical." ${ }^{114}$ But in fact, they didn't actually exempt worship from any restrictions, unlike all other "critical" activities. Instead, worship services could continue through "streaming or other technologies" only, while other beneficiaries in the "critical" category-film studios, cannabis dispensaries, and laundromats, to name a few-faced no such restrictions. ${ }^{115}$ By the time the Court considered South Bay, the state had recategorized churches as "high-risk workplaces," but it continued to provide special privileges to all other entities originally labeled "critical infrastructure."

My view is that strict scrutiny should apply in this instance too, though I admit it presents a closer question. California technically placed houses of worship in the "critical infrastructure" category. But it didn't actually allow churches or mosques to meet the way movie studios could. And unless general applicability is just an empty formalism, it's hard to see why government should be able to avoid the requirement so easily. If the state in Sherbert had formally declared that Adell Sherbert's Sabbath observance qualified as "good cause" but still refused to pay her, it seems obvious that strict scrutiny still ought to apply. The same would seem to be true in these circumstances too. ${ }^{117}$

At this point, it's important to make two final observations before turning to some larger issues. The first involves a basic question. In pointing to the rule against subjective or valuebased distinctions as a way of analyzing the COVID-19 church-closure cases, much of what

${ }^{113}$ Cal. Exec. Order N-33-20 (Mar. 19, 2020), https://www.library.ca.gov/wp-content/uploads/ GovernmentPublications/executive-order-proclamation/40-N-33-20.pdf; see also Essential Critical Infrastructure Workers (Apr. 28, 2020), https://files.covid19.ca.gov/pdf/EssentialCriticalInfrastructureWorkers.pdf (describing the various categories). In compiling the included entities, the state drew on a list of "critical infrastructure" sectors provided by the Department of Homeland Security, but also added additional entities including film studios and cannabis dispensaries. See Department of Homeland Security, Critical Infrastructure Sectors (Oct. 21, 2020), https:// www.cisa.gov/critical-infrastructure-sectors.

${ }^{114}$ See Essential Critical Infrastructure Workers, supra note 113, § 8: Government Operations \& Other Community-Based Essential Functions, II 16.

${ }^{115}$ Id. (including "faith-based services that are provided through streaming or other technologies"). See also id. § 13: Industrial, Commercial, Residential, \& Sheltering Facilities, II 15 (film industry); id. § 1: Healthcare/Public Health, II 7 (cannabis), II 4 (laundromats). Nor was California the only State to pursue this strategy. See, e.g., Wisconsin Emergency Order \#28 (Apr. 16, 2020), https://evers.wi.gov/Documents/COVID19/EMO28-SaferAtHome.pdf (classifying religious entities as "essential businesses and operations" but limiting all religious gatherings with a hard ten-person cap).

${ }^{116}$ See Update on California's Pandemic Roadmap (May 7, 2020), at 12, https://www.gov.ca.gov/wp-content/ uploads/2020/04/Update-on-California-Pandemic-Roadmap.pdf.

117 One possible exception may have been Tandon itself-the case in which the Court clarified the meaning of the comparability aspect of general applicability. Unlike the other cases involving California's restrictions, Tandon didn't involve a challenge by a public-facing house of worship like those California considered when introducing its "critical infrastructure" designation. Instead, it involved a challenge by plaintiffs who wished to conduct in-home Bible studies free of the state's more severe restrictions on private gatherings-private-facing religious activities that, at least arguably, the state's “critical infrastructure" designation simply didn't contemplate. See Tandon v. Newsom, 141 S. Ct. 1294, 1297 (2021) (noting that the plaintiffs wished to engage in "at-home religious exercise"). And in that instance, where the textual inference of a negative value judgment is weaker, the need to answer harder questions involving comparability becomes more pronounced. 
I've said turns on the fact that these regulations explicitly differentiated among gatherings using terms like "essential" or "critical." But if that's true, couldn't New York or other states have dealt with the problem by just deleting the troublesome words while leaving the rest of their restrictions in place? And if so, isn't this theory just an empty solution?

I think it's fairly well settled that the answer to that question is no. The reason has to do with the relationship between neutrality and general applicability. Although these are separate requirements, they are mutually reinforcing. As a result, the Court has said that, when considering whether a law complies with the Free Exercise Clause, courts should consider the circumstances surrounding a law, including "the historical background of the decision" and the "specific series of events" leading up to it. ${ }^{118}$ Under that rule, it seems clear that merely deleting words like "essential" or "critical" while leaving everything else in place wouldn't be enough to rebut the conclusion that a state's regulations still depended on a negative assessment of religion's value. Moreover, even assuming that a state chose to make larger changes, those changes must still satisfy the strand of general applicability focused on comparability-now informed by an earlier strict scrutiny analysis. Simply removing the troublesome words isn't enough to satisfy the Constitution, especially when the inference of a negative value judgment remains obvious.

A second observation involves the limits of my argument. Under my reading of the general applicability requirement, many of the COVID-19-related regulations considered at the Court (and many others around the country) presumptively violated the First Amendment by requiring officials to declare worship "nonessential" as a condition for regulating it. But that doesn't necessarily mean the Constitution requires treating churches or synagogues the same as grocery stores or hospitals. Rather, it means the government must produce evidence that it has a compelling interest in regulating a particular house of worship more stringently and that there really are no less restrictive means of protecting that interest. Saying that regulations may not discriminate against religion by drawing value-based distinctions doesn't prevent courts from ultimately concluding that some restrictions should be lifted while others can be maintained, as the Supreme Court sometimes did. ${ }^{119}$ Nor does it mean the Court was necessarily wrong in early cases like South Bay, when little was known about the virus or the effectiveness of strategies to combat it. The point is that regimes regulating religion based on subjective or value-based categories trigger strict scrutiny, not that they trigger automatic exemptions.

In resolving the COVID-19 church-closure cases, the Court focused on comparability. But, in fact, the cases also might have been resolved with reference to the aspect of general applicability focused on subjective or value-based categories.

\section{Objections and Implications}

A more fulsome understanding of the general applicability requirement provides an alternative explanation for many of the church-closure cases. But that claim is also subject to several important objections. Below, I briefly examine a few of them and explore some larger insights the theory might contain for the meaning of the Free Exercise Clause.

\section{"Adequate Alternatives"}

As I've argued above, a correct understanding of general applicability indicates that COVID-19-related restrictions that explicitly required officials to designate worship as "nonessential" likely violated the Free Exercise Clause. But one might respond-as some commentators and judges did-by simply defending the designation on the merits. On

\footnotetext{
${ }^{118}$ Masterpiece Cakeshop v. Colorado Civil Rights Commission, 138 S. Ct. 1719, 1731 (2018).

119 See Harvest Rock Church v. Newsom, 141 S. Ct. 1289 (2021) (enjoining enforcement of a ban on indoor worship services but upholding 25 percent capacity limitation and restrictions on singing and chanting).
} 
this view, acupuncture parlors and cannabis dispensaries actually are more essential than worship services, because "there may be no other way to procure an exempted essential service but to physically go somewhere in person, while alternatives exist for religious services." 120 Probably the most notable defender of this view, Judge Frank Easterbrook, put it memorably: "Feeding the body requires teams of people to work together in physical spaces, but churches can feed the spirit in other ways." 121

of all possible responses, this one is the least persuasive. From the point of view of religious claimants in these cases, online worship services were not an adequate alternative to in-person worship; that's the whole point. And very often, that's so for quite understandable reasons. For the Catholic claimants in Diocese of Brooklyn, for instance, the most important part of a worship service is receiving bread and wine consecrated by a priest-an act that can't be done remotely, and one that is impossible to accomplish through delivery where the number of parishioners runs in the hundreds or thousands. And the same is true of countless other religious practices, which depend upon rituals or communal activities that simply can't be replicated at a distance. ${ }^{122}$

But there's also a more fundamental point here-this one going to the heart of the Free Exercise Clause. It's true that some religious groups might consider remote worship an adequate substitute in some instances. But it's important to understand that the argument about adequate alternatives doesn't end there. Rather, the claim that "churches can feed the spirit in other ways" implies a power on the part of government to decide when "other ways" are good enough.

The logic of that position is odious to the First Amendment. As James Madison observed long ago, government is not "a competent Judge of Religious Truth." ${ }^{23}$ As a result, it possesses no authority to tell religious believers which aspects of their worship are truly essential and which are not. If the government chose to ban religious circumcisions on the grounds that they were not "essential," would anyone claim it could justify that law by simply asserting that, in fact, Jews have been wrong for two thousand years and less gruesome alternatives will suffice? In my view, the answer is self-evident, such that no more needs to be said. Government does not get to tell believers which parts of their worship are expendable and which are not. And that bedrock principle should be enough to put this argument to rest.

\section{Individualized Assessments}

A second possible response to my proposal would be to accept that many COVID-19 mitigation regulations likely violated the rule against value-based distinctions, but to argue that the rule itself is incoherent. The reason, the argument goes, is that all laws depend to some extent "individualized assessments" about the conduct in question, including value judgments about it. On this view, the individualized assessment doctrine-including the rule against value-based distinctions-simply collapses on itself.

Unlike the objection about adequate alternatives, this objection has some plausibility. After all, it seems clear that Justice Scalia recharacterized Sherbert and similar cases as

\footnotetext{
${ }^{120}$ Caroline Mala Corbin, Religious Liberty in a Pandemic, 70 DuKe LaW Journal OnLine 2, 17 (2020).

${ }^{121}$ Elim Romanian Pentecostal Church v. Pritzker, 962 F.3d 341 (7th Cir. 2020).

${ }^{122}$ See, e.g., Church of Jesus Christ of Latter-Day Saints, About the Temple Endowment, https://www.churchofjesuschrist.org/temples/what-is-temple-endowment?lang=eng (explaining that "your temple endowment is one of the most sacred experiences of your life," and that "[o]nly in the temple can we receive the ordinances necessary for us to be exalted in the celestial kingdom . . . . including the endowment"); Ishola Balogun, Observing I'tikaf, VANGUARD News (Aug. 10, 2012), https://www.vanguardngr.com/2012/08/observing-itikaf-2/ (explaining the Muslim practice of I'tikaf, and observing that "[o]ne must stay inside the Mosque for the entire period for his I'tikaf to be correct").

${ }^{123}$ See James Madison, To the Honorable General Assembly of the Commonwealth of Virginia: A Memorial and Remonstrance against Religious Assessments, reprinted in James Madison on Religious LiberTy 55, 57 (Robert S. Alley, ed. 1985).
} 
involving "individualized assessments" to revamp the Court's free exercise doctrine in Smith without overruling those cases. ${ }^{124}$ Later, the Court reaffirmed the individualized assessment doctrine in Lukumi and Masterpiece Cakeshop, and extended it to include not just laws conferring unfettered discretion, but also laws employing subjective or value-based criteria. ${ }^{125}$ But given its dubious origins, one might question whether the doctrine itself actually makes sense.

In fact, though, Justice Scalia's instincts were better than he knew. Although likely invented as a device to distinguish Sherbert and similar cases, the rule against individualized assessments provides a sensible way to guard against the concerns over religious discrimination that animate the Court's post-Smith jurisprudence.

Begin with the original version of the rule as articulated in Smith, and recently reaffirmed in Fulton. In those cases, the Court said that laws containing a "formal system of entirely discretionary exemptions" weren't generally applicable, because they "invite" officials to grant or withhold exemptions based on impermissible reasons. ${ }^{126}$ In Fulton, the Court didn't explain the logic of that rule. But as others have observed, it mirrors rules governing licensing regimes in the free speech context, and is justified for many of the same reasons-where discretion is at a maximum, "the risk of bias is sufficiently high, and the effectiveness of after-the-fact review sufficiently low . . that a prophylactic rule is necessary." ${ }^{27}$ Where the law explicitly grants low-level officials broad discretion to discriminate, courts should closely scrutinize whether they are using that discretion in a way that actually conforms to the Constitution.

But what about the expansion of the rule in cases like Lukumi and Masterpiece? Even if the basic rule about individualized assessments is sound, does it really make sense to expand it to cover any instance where the application of a law is explicitly conditioned on a subjective standard? After all, aren't all laws that draw distinctions dependent on value judgments to a greater or lesser extent?

This objection fails because it's built on an exaggeration. To see why, an example is helpful. Imagine that a jurisdiction has a law requiring all vehicles to stop at red lights but exempting emergency vehicles. In drafting that law, legislators undoubtedly made a value judgment that saving citizens from serious injury or death was important enough to justify an exception to its traffic laws. But nothing on the face of that law suggests that religion was ever considered. Nor does applying that law to a religious driver-say, a worshiper late for church-require any such consideration. Unlike a law allowing people to ignore red lights for "good cause," nothing in this law requires officials to consider a driver's specific reasons for failing to stop. Instead, it merely requires a binary judgment: is this car an emergency vehicle or not? A law like that might imply a value judgment in some general sense. But nothing in its text implies a value judgment about religion that signals a need for heightened scrutiny under the individualized-assessment framework that Lukumi and other cases set out.

To be sure, though, maybe this isn't the end of the matter. Critics of the individualized assessment doctrine have sometimes argued that the doctrine is incoherent because police officers and prosecutors frequently make case-by-case judgments when making arrests or charging crimes. ${ }^{128}$ Returning to our example, then, if applying the red-light law invariably involves discretion about whether to issue a ticket or bring a prosecution, doesn't this prove the rule against value-based assessments is fundamentally unworkable?

\footnotetext{
${ }^{124}$ See Michael W. McConnell, Free Exercise Revisionism and the Smith Decision, 57 University of ChICAgo LAW ReVIEW 1109, 1124 (1990) (arguing that the Court's treatment of Sherbert and related cases in Smith had "one function only: to enable the Court to reach the conclusion it desired in Smith without openly overruling any prior decisions").

${ }^{125}$ See supra notes 67-92 and accompanying text.

${ }^{126}$ Fulton v. City of Philadelphia, 141 S. Ct. 1868, 1877-78 (2021); see also Employment Division v. Smith, 494 U.S. 872, 884 (1990).

${ }^{127}$ Brownstein, supra note 62, at 194.

${ }^{128}$ See, e.g., Nelson Tebbe, The Principles and Politics of Liberty of Conscience, 135 HarVard LaW Review 267, 299-300 (2021) (making this argument).
} 
Here again the answer is no, but for a different reason. It's true that in our system, application of every law depends to some degree on discretionary choices by executive officials. But equating prosecutorial discretion with laws explicitly requiring individualized assessments elides a key distinction. As written, most civil and criminal laws don't authorize officials to discriminate on forbidden bases like race or religion. Nor could they, because doing so is almost always unlawful. Instead, these laws-like the red-light example above-employ objective, nondiscriminatory criteria, and the law presumes prosecutors will enforce them in a nondiscriminatory way unless a claimant proves otherwise. ${ }^{129}$ But where a law explicitly confers significant discretion or employs value-based distinctions, the situation is different. Unlike other laws, these laws on their face invite officials to consider the religious reasons for conduct when applying or enforcing the law against a religious actor. And as a result, the Court's free exercise jurisprudence demands that such laws be scrutinized more closely.

The rule against individualized assessments probably originated as a convenient way to distinguish cases the Court had to explain in Smith. But it is also a sensible way to police impermissible discrimination against religion, especially where laws explicitly depend on making a negative value judgment about religion as a condition of their enforcement.

\section{Discrimination}

This last point leads to a third objection, this one probably the most significant. So far, I've argued that a law isn't generally applicable where it both regulates religion and explicitly conditions its application on a subjective standard-whether conduct amounts to "good cause," whether worship is "essential" and so on. But admittedly, this might differ from how the law conceptualizes discrimination in some other contexts-those involving free speech, for instance, and possibly discrimination on the basis of race. And if those other areas wouldn't recognize discrimination in these instances, why would the Free Exercise Clause be different?

To understand this objection, it helps to focus on a few hypotheticals. Imagine that a state designates a minority-owned movie theater as "nonessential" alongside others and thus subject to more severe restrictions under its COVID-19 mitigation regime than businesses in the "essential" category. Under current equal protection doctrine, the owner has a valid discrimination claim if she can show that the state shuttered her business "at least in part 'because of,' not merely 'in spite of" race. ${ }^{130}$ Yet it seems unlikely that a court would conclude that burden had been met solely based on the "nonessential" designation. And if that's true in this context, why shouldn't it also be true as to free exercise?

Or consider another example, this one involving free speech. Imagine an activist is prosecuted under a law banning the destruction of draft cards after burning his card during a protest. Under current free speech law, the fact that he burned his card for expressive reasons isn't a basis for applying strict scrutiny, because both the law and its application can be justified by "an interest . . . unconnected to expression" like protecting the integrity of the draft system. ${ }^{131}$ And very likely, that same conclusion would follow even if the law contained an exemption for "essential" acts of destruction. The mere fact that applying the law requires designating protest burnings as "nonessential" isn't enough to prove government has targeted speech, because the same speech-neutral justifications still exist. And if that's true in the free speech context, why would religion be any different?

\footnotetext{
${ }^{129}$ See, e.g., Armstrong v. United States, 517 U.S. 456, 465 (1996) (concluding that discriminatory prosecution claims may proceed, but only when supported by "clear evidence" of discrimination such as the failure to charge similarly situated persons).

${ }^{130}$ Personnel Administrator of Massachussetts v. Feeney, 442 U.S. 256, 279 (1979).

131 Texas v. Johnson, 491 U.S. 397, 407 (1989); see also United States v. O’Brien, 391 U.S. 367, 378-79 (1968) (upholding the prosecution of a protestor for burning his draft card on this ground).
} 
These are powerful arguments, at least on the surface. But they also suffer from a common flaw. They fail to appreciate why these areas of law analyze government motive the way they do, and consequently how the Free Exercise Clause differs. Although the Court's post-Smith jurisprudence has drawn on speech and equal protection doctrine in forming its requirements, the Free Exercise Clause is based in concerns separate from both of those areas. And in a context like the COVID-19 church-closure cases, recognizing those unique concerns is the key to understanding the kind of discrimination the Free Exercise Clause prohibits.

Begin with the case about the minority business owner whose movie theater is declared "nonessential" along with other theaters. Under current equal protection law, the owner has a discrimination claim if she can show the state regulated her business "at least in part "because of" race. ${ }^{132}$ Yet it seems unlikely that a court would draw that conclusion based on the "nonessential" designation alone. Why would religion be different?

Here, the answer has less to do with the Constitution than it does with a difference between the two cases. In drawing the parallel between the real church-closure cases and the hypothetical case about race, the argument assumes that labeling a minority-owned movie theater "nonessential" tells us the same thing about government purpose as labeling religious worship that way. But in fact, it does not. In the real church-closure cases, there's no question that states like New York took religion into account, because the structure of the regulations ensured that worship could be regulated only after officials determined that gathering for religious reasons was not "essential." By contrast, classifying a movie theater as "nonessential" doesn't give rise to an inference of discrimination (at least without more), because owning movie theaters is not, in itself, a race-specific endeavor. Whereas "worship" is an activity fraught with religious significance, owning movie theaters is an activity that people of all races pursue. In these two cases, regulating the relevant activities with an "essential" designation just works differently.

There's also an additional point here. In the equal protection context, a plaintiff can make out a prima facie claim of discrimination by showing that a discriminatory purpose-that is, a purpose based on race or religion-was "a motivating factor" in the decision. ${ }^{133}$ Yet under the Equal Protection Clause, the Court has also mandated a burden-shifting framework, in which the government can prevail if it proves that "the same decision would have resulted even had the impermissible purpose not been considered." ${ }^{134}$ In the church-closure cases, state governments frequently pointed to the special risks posed by churches and worship services as the reason for differential treatment. And if those kinds of arguments would be sufficient to rebut a charge of discrimination in the race context, why wouldn't they be sufficient as to religion?

Here again, the answer is more straightforward than it first appears. In the churchclosure cases as in many racial discrimination cases, the government had a possible alternative explanation for differential treatment-worship services are riskier than other activities. Recall, though, that in the actual cases, those arguments depended almost entirely on broad generalizations about what "usually happens" at a worship service. ${ }^{135}$ Yet under the Court's equal protection doctrine, those kinds of broad generalizations aren't enough. The Constitution doesn't allow "even a true generalization about [a] class [to] justify class-based treatment." ${ }^{136}$ Instead, government must produce evidence that the differential treatment

${ }^{132}$ Feeney, 442 U.S. at 279.

133 Village of Arlington Heights v. Metropolitan Housing Development Corporation, 429 U.S. 252 , 266 (1977).

134 Id. at 270 n.21.

135 See supra, note 46-50 and accompanying text (explaining this point).

136 See Arizona Governing Commission for Tax Deferred Annuity \& Deferred Compensation Plans v. Norris, 463 U.S. 1073, 1085 (1983) (Marshall, J., concurring in part) (citation and internal quotation marks omitted); see also City of Los Angeles v. Manhart, 435 U.S. 702, 707-11 (1978) (rejecting the argument that a retirement policy that facially discriminated between men and women could be justified based on life tables showing that women generally live longer). 
was justified as to the specific party claiming discrimination. And in applying strict scrutiny in cases like Diocese of Brooklyn, that's exactly what the Court was doing-asking for religionneutral reasons based on actual evidence about the parties rather than broad generalizations about "worship services" writ large. The Equal Protection Clause and the Free Exercise Clause are different. But as to the COVID-19 church-closure cases, at least, they don't actually point in different directions.

But what about free speech? As noted above, under the Court's current doctrine, a protestor can be prosecuted for burning his draft card under a law generally forbidding a card's destruction, and the same would likely be true even if the law required an official judgment that protest-motivated burnings are not "essential." The reason, as I've already observed, is that there's also a sufficient non-speech-related justification available. And where that's so, the Court's expressive conduct doctrine says strict scrutiny doesn't apply. But that more deferential approach to government motive isn't just a given. Rather, it's justified by the specific concerns underlying the Free Speech Clause.

At its heart, the Constitution's protection of free speech aims to ensure that discourse on public issues remains "uninhibited, robust, and wide open" by limiting government's power to censor ideas or drive them from the marketplace. ${ }^{137}$ Yet in the context of laws regulating conduct, that danger is largely absent. In all but the rarest cases, regulating conduct that is also expressive doesn't actually prevent an idea from being expressed. Instead, it simply drives it to another medium: the spoken or written word. And to ensure that's true, even content-neutral regulations of speech must leave open "ample alternative channels." ${ }^{138}$ To be sure, there may be instances where the message carried by some act is so evocative or powerful it can't be transmuted into speech. But those are precisely the cases in which government will be most tempted to regulate conduct based on its expressive characterand thus, the cases that the Court's more limited motive inquiry actually takes into account. The Court's expressive conduct jurisprudence employs a deferential motive analysis because it assumes that, in all but the rarest instances, regulations of conduct alone do not (and really cannot) significantly curtail speech.

The Free Exercise Clause is different, in at least two important respects. First, unlike the Free Speech Clause, it explicitly protects conduct-specifically, religious "exercise." ${ }^{139}$ But just as importantly, it protects conduct that almost always does not have a readily identifiable substitute. If a police officer grows a beard to protest what he sees as the department's draconian grooming policy, enforcing the no-beard rule doesn't stop him from spreading his message in other ways. But if a police officer's religion demands he grow a beard and the department forbids it, there's no alternative means of fulfilling his duty to God-he can either obey the religious command and lose his job, or betray his faith. ${ }^{140}$

Of course, the mere fact that the policy puts the officer to that choice probably isn't enough to create a free exercise violation-that's the point of Smith. But recognizing that regulations of conduct can have a much more destructive effect on religion than they do on speech provides a reason to treat discrimination in free exercise cases differently, and with less deference to the government. And indeed, at least if the Court's discussion of the issue in Lukumi and elsewhere is our guide, there's a good argument that this more searching inquiry is the one the Court has already adopted.

Consider first Lukumi's treatment of Sherbert. When discussing the "individualized assessment" in Sherbert, the Court didn't ask whether some other reason was sufficient to explain

\footnotetext{
${ }^{137}$ New York Times Co. v. Sullivan, 376 U.S. 254, 270 (1964).

${ }^{138}$ McCullen v. Coakley, 537 U.S. 464, 477 (2014).

${ }^{139}$ See U.S. Const. amendment 1.

${ }^{140}$ For a nice discussion of this point, see Christopher C. Lund, Religion Is Special Enough, 103 VIRGINIA LAW REVIEW 481, 522 (2017) (noting that, unlike restrictions on religious practice, most speech restrictions "leave other opportunities for speech open").
} 
the denial of benefits in that case, though it certainly could have based on its facts. ${ }^{141}$ Rather, the Court was content to conclude that laws like the one in Sherbert triggered strict scrutiny because they explicitly instructed officials to "asses[s] the reasons for the relevant conduct" and allowed them to deny benefits after concluding religion didn't qualify as "good cause," whatever other bases for denial might have also been present. ${ }^{142}$

The same thing is true of the other unemployment cases. In Hobbie v. Unemployment Appeals Commission-one of the cases in Sherbert's line-the Court considered a free exercise claim by a religious worker who had been fired from her job after converting to Seventh Day Adventism and informing her employer she could no longer work on Saturday. ${ }^{143}$ The state denied unemployment benefits, arguing that because Paula Hobbie changed her religion after taking the job, her refusal to work on Saturdays constituted "misconduct" that made her ineligible. ${ }^{144}$

There was no question that enforcing the rule against Hobbie could have been justified on a variety of religion-neutral grounds-protecting her employer's reliance interests, for instance, or protecting the unemployment system from the financial burden created by after-the-fact refusals. ${ }^{145}$ Nonetheless, Justice Brennan and seven other justices cast those concerns aside. Instead, they reasoned that a scheme which "labels and penalizes behavior dictated by religious belief as intentional misconduct. . . exhibits greater hostility toward religion than one deeming such resignations to be "without good cause."146 The same would seem to be true of a regime that explicitly labels worship "nonessential" and subjects it to harsher regulation, even if some other religion-neutral justification might also be available. Under these cases, the question is whether government took account of an activity's religious aspect when deciding whether to regulate it, not whether regulating religion is the government's only purpose. Free exercise and expressive conduct simply work differently, and with good reason.

In sum, the conclusion that heightened scrutiny ought to have applied to COVID-19related regulations labeling worship "nonessential" doesn't require special pleading about discrimination. Instead, it just requires an appreciation of the differences between various constitutional provisions where questions of discrimination are relevant. The Free Exercise Clause is unique, even if it shares certain doctrinal tools with other areas. And once that's clear, it provides even more reason to think that the Court was correct in Diocese of Brooklyn and similar cases, albeit for different reasons than the ones the Court chose to focus on.

\section{Conclusion}

The Court's decisions in the COVID-19 church-closure cases have been heavily criticized. But in my view much of that criticism is probably unjustified-or at the very least, it doesn't take the full picture into account. Under the Free Exercise Clause, where a law treats some things better than others based on judgments about what counts as "good cause," "necessary," or "essential," one of those things must be religion, absent compelling reasons to the contrary.

\footnotetext{
${ }^{141}$ Compare Sherbert v. Verner, 374 U.S. 398, 407 (1963) (rejecting the argument that application of the "good cause" standard could be justified based on the state's interest in preventing "the filing of fraudulent claims by unscrupulous claimants"); with United States v. O’Brien, 391 U.S. 367, 279-80 (1968) (accepting the government's argument that prosecution of a protestor for burning a draft card was permissible, in part because "a mutilated certificate might ... be used for deceptive purposes").

142 Church of the Lukumi Babalu Aye, Inc. v. City of Hialeah, 508 U.S. 520, 537 (1993) (quoting Employment Division v. Smith, 494 U.S. 872, 884 (1990)).

${ }^{143} 480$ U.S. 136 (1987).

${ }^{144}$ Id. at 138 .

${ }^{145} \mathrm{Id}$. at 143-44 (considering and rejecting these arguments).

${ }^{146} \mathrm{Id}$. at 142 n.7.
} 
The Constitution demands nothing less. And in truth, Diocese of Brooklyn and the other church-closure cases very likely demanded nothing more.

Acknowledgments. Thanks are due to Stephanie Barclay, Will Baude, Kathleen Brady, Sam Bray, Nicole Bronnimann, Jud Campbell, Charlie Capps, Nathan Chapman, Jamie Colburn, Justin Latterell, Chris Lund, Andy Koppelman, Michael McConnell, Zalman Rothschild, and John Witte, Jr. All errors, of course, are mine alone.

Cite this article: Storslee, Mark. "The COVID-19 Church-Closure Cases and the Free Exercise of Religion." Journal of Law and Religion 37, no. 1 (2022): 72-95. https://doi.org/10.1017/jlr.2021.81. 